Charo Lacalle

\title{
Young people and television fiction. Reception analysis
}

DOI 10.1515/commun-2015-0006

\begin{abstract}
This article presents the findings of an audience research conducted with 86 young Spanish people aged 15 to 29 years. The investigation examines the modes of reception of television fiction, and the impact of the shows on the viewers. Friends' influence on the choice of program, and the tendency to use social networks to comment on the shows and to talk about themselves, underline the crucial role played by TV fiction and new technologies in socialization processes. While most participants criticized the propensity of television fiction to build extreme stereotypes, they also showed a clear predilection for Spanish programs, and admitted that their characters often offer inspiration to face everyday problems.
\end{abstract}

Keywords: reception, television, fiction, young people, gender

\section{Introduction}

The interest in the 'active audience' raised by the Cultural Studies in the second half of the 1980s consolidated a very productive and enormously influential line of research, aimed at analyzing the reception and interpretative processes of television texts. The impact of pioneer works by Tania Modlesky (1979), David Morley (1980), Dorothy Hobson (1982) and Ien Ang (1985), among others, determined the methodologies and the fields of study. Since then, reception analysis has adapted some ethnographic techniques, such as focus groups or interviews (Livingstone, 1991), and combined them with different types of discursive analyses (Hoijer, 1990).

Unlike the first works by David Morley, reception analysis minimized the impact of social class, as Morley (1986) himself subsequently predicted, in order to focus on the influence of other social factors such as gender, age, ethnicity,

Charo Lacalle, Universitat Autonoma de Barcelona - Journalism, Campus Bellaterra, Bellaterra, Barcelona, 08193 Spain, E-mail: rosario.lacalle@uab.es 
and family influence. Fears associated with the possible adverse effects of television on children, and concern over the inherent problems to adolescence, however, resulted in a lesser interest in young viewers (Lacalle, 2010; Von Feilitzen, 2008). In recent years, transmedia processes of television fiction (Jenkins, 2006), increasing feedback from viewers (Ross, 2008), and the narrative complexity of programs (Mittell, 2006) have led youth to progressively become a target for this TV genre, now a close ally to the internet. As a result, this social group is now at the forefront of communication research.

This article summarizes the key findings of a research about reception of Spanish TV fiction among young people, which combines focus group interviews and a questionnaire. ${ }^{1}$ The active nature of the audience, finding satisfaction in television reception, the relevance of context as well as the possible influence of fiction in socialization and identity building processes provide the framework for this study, which combines contributions from the Uses and Gratifications Model with Cultural Studies.

The investigation is part of a larger project regarding the construction of youth identities in fiction, integrated with the socio-semiotic analysis of characters and viewers' discourses on the web 2.0. The main interest of this part of the research lies in the suitability of reception analysis to explain the construction of meanings that takes place during the reception processes (Wilkinson, 1998). This is an area of increasing interest in Spain, in line with the gradual upsurge of domestic fiction since 2000, the rise in exports ${ }^{2}$ and the excellent ratings of some shows, which go far beyond the average of their TV networks (Lacalle, Castro, and Sánchez, 2014). Likewise, the commitment of Spanish TV fiction to transmediality and the ongoing incorporation of youth targets to prime time series has greatly rejuvenated the average age of the viewers of two of the main generalist TV networks, La1 (public) and Antena3 (privately owned).

\section{Methodology}

Due to the importance of interpersonal relationships among young people, the nine focus groups in this research consisted of people who knew each other

1 We take on the classical dichotomy fiction/factuality to define television fiction as a macrogenre comprising stories about events and/or characters totally or partially fabricated. Television fiction is articulated in different genres (drama, comedy, dramedy, crime, adventure, etc.) and formats (series, serials, miniseries, TV movies and sketches).

2 MIPCOM, held in the French city of Cannes in May 2014, confirmed Spain as the fifth largest exporter of TV formats in the world and the best seller of comedy formats in 2013/14. See The 
previously. The aim was to recreate the natural environment of their everyday communication in the least contrived way (Baym, 2000; Biltereyst, 1991; Kitzinger, 1994). Thus, most participants were friends, although sometimes they had other kinds of relationships (classmates, family) that did not necessarily exclude friendship but led to a different group configuration. Similarly, the number of young people in each focus group interview ranged between 8 and 12 in order to respect the established distribution of the pre-existing groups. ${ }^{3}$ It was, therefore, a convenience sample, comprising individuals used in intercourses with members of the same group, but brought together with the rest of the groups only according to age.

The research involved 86 young people, 55 women (64\%) and 31 men (36\%) between the ages of 15 and 29, divided in three age ranges (15-17, 18-23 and 24-29). Interest in studying reception from a gender perspective, and the fact that women watch more TV fiction than men, led to incorporating an allwomen group. The remaining eight groups included a balanced proportion of young male and female participants. In order to maintain territorial representation, the focus groups were conducted in the Spanish Autonomous Communities that produce television fiction (Catalonia, Andalusia, Galicia, Basque Country, Valencia and the Balearic Islands), as well as in Madrid and Aragon.

Each focus group was preceded by an individual, anonymous questionnaire aimed to provide some quantitative data to contextualize the interview in relation to the participants. Furthermore, by comparing the questionnaire's answers and some opinions manifested during the interviews we were able to validate the reliability of the answers.

Observations made by researchers were an essential complement to the methodology (Baym, 2000), as were paralinguistic and communicational codes, considered by Gumperz (1992) to be essential signs of relationships among group members. Consequently, transcriptions of the participants' interventions combine "interpretative sensitivity" with "systematic coding” (Hoijer, 1990). Although some authors caution that such compilation may be time-consuming (Lunt \& Livingstone, 1996), the template used in our research was extremely useful to structure participants' interventions. Simultaneously, the reflection inherent to a codification process allowed us to examine focus groups' results

wit guide to scripted formats 2014 (retrieved September 28, 2014 from http://www.my-mip.com/ resource-centre/white-papers/the-wit-guide-to-scripted-formats-2014/).

3 Experts do not generally establish the number of participants in each focus group interview rigidly. Some researchers advocate a flexible form between 6 and 10 participants (Lunt and Livingstone, 1996), while others raise the number of participants according to the objectives (Losito, 2009). 
from the critical perspective required by this type of methodology (Holliman, 2005).

The analysis shows three consecutive phases. First, the data collected from the questionnaires was processed using the statistical software SPSS. The results of the computer coding provided 69 frequencies (one for each variable in the SPSS database), which represent the total number of applications of each value of the category to all participants. During the second phase the group interview transcripts were disaggregated by using a structured template that followed the socio-semiotic script used during the focus group interviews. Finally, the interpretation of the 138 contingency tables generated by crossing the two independent variables (gender and age) with the remaining variables allowed us to contextualize the discursive analysis of the interventions, which is summarized below.

To synthesize and organize the results, we used as a reference the Adolescents' Media Practice Model by Jeanne Steel and Jane Brown (1995). The model, developed by the authors to examine the role of media in the process of construction of adolescent identity, ${ }^{4}$ understands identity formation as a key component of adolescent development.

The model incorporates identity formation, the central task of adolescent development, as a key component [...] Teens' sense of who they are shapes their encounters with media, and those encounters in turn shape their sense of themselves in the ongoing process of cultural production and reproduction. (Steel and Brown, 1995, p. 557)

The Steel and Brown model was inspired by authors such as Bentley (1987) and Bourdieu (1990), and is focused on the everyday practices and consumption of media from a practical perspective (Steel and Brown, 1995, p. 556). It also tackles questions such as "lived through experience" (Vygotsky, 1978; Wertsch, 1991), "a theoretical perspective that accounts for developmental stage, the sociocultural influences of race, class, and gender, as well as many other socializing factors" (Steel and Brown, 1995, p. 557).

The Adolescents' Media Practice Model structures the role played by the media in shaping identities in three phases: selection, interaction and application. The impact of new media on the reception processes, however, makes it necessary to use this model, formulated in 1995, in a flexible way. In order to adapt the model to the current television context it was essential to add a new

4 Although Steel and Brown conceive their model of media selection, interaction, and application as constantly shaping and being shaped by identity, they are more interested in media components than the identity component of the model. Hence, the process of construction of identity is not tackled in a specific way in our article. 
intermediate step that clearly emerges from our research, and is different from interaction: negotiation. This was a key element for the age group 18 to 23, whose narrative skills and critical ability generally surpassed those of the rest of the participants.

Likewise, the particular characteristics of this study lead us to privilege the detailed description of results from the focus groups over other types of data analysis. Consequently, description and excerpts are limited. In general terms, however, we subscribe to the importance some authors give to them (Stevens, 1996; Wilkinson, 1998).

\section{Selection}

Steel and Brown define Selection as the "the act of choosing among mediarelated alternatives", influenced by motives such as those described in the "selective exposure" and "uses and gratifications literature" (Steel and Brown, 1995, p. 558).

Participants in the focus group unanimously believed fiction is a fun way to prevent boredom, and they admitted it helps them to escape problems and daily responsibilities, a function systematically observed by Cultural Studies researchers. Thus, television fiction was the interviewees' preferred genre (98\%), although only $29 \%$ followed their favorite program regularly, while $36 \%$ watched it frequently. Women were more loyal to fiction than men. By age, young people from 24 to 29 were the most regular viewers, while some participants in the age group 18-23 watched fiction only occasionally. Nevertheless, most participants admit that, once they start watching, they easily become "addicted" to fictional TV shows.

\subsection{Programs and characters}

Generally speaking, respondents preferred comedy over drama, partly because they found it entertaining. When choosing programs, however, female participants in our research were inclined towards dramas aimed at the youth target audience (El internado, Física o química, and Los protegidos, Antena 3), while men preferred Spanish sitcoms (Siete vidas and Aida, Tele5). By age, participants aged 15 to 17 preferred programs aimed at youth, while those aged 18 to 23 preferred comedy. Dispersion in the responses of young adults (24 to 29) did not allow to drawn a clear conclusion. 
Friendship and love subject matters were key factors in the choice of programs. The participants, however, did not seem to find violent content attractive, a result along the same lines of previous research (Lemish, 1998; Weaver and Wilson, 2009). Physical appearance was also important with regard to women's preferences, especially among younger girls. Thus, as Gavin (2001) points out, this fact validates the role of gender as a hermeneutic tool for shaping audience understandings.

A. (female), Barcelona, 18-23 years old: Of course, attractive characters draw our attention; even younger people are attracted to them, because now they start very early. Why do you think they show Mario Casas in El barco and not Luisma? ${ }^{5}$

Broadly speaking, participants in our focus groups liked comical characters, bad guys, and rebels better than dramatic characters and good guys. Ambivalent characters were also highly appreciated.

F. (female), Zaragoza, 24-29 years old: I like series in which characters change, the one who seemed to be the good guy, suddenly something happens and becomes evil, and then they could be good and bad again. I believe these games give depth to the characters, and they seem much more real than those unrealistic constructions of good is good, and bad is bad. 6

Participants aged 24 to 29 were attracted to confident characters, as well. The most popular characters were men and, unlike those "handsome" ones, which usually were younger, the "funny" ones were mostly adults. Absurd and extreme characters were preferred by respondents wanting to be entertained by fiction, a type of gratification more valued among male than female participants in our research.

Like in the cinema, actors and actresses can play a crucial role in the election. Famous actors, however, were not necessarily the most beloved. Quite the opposite, Spanish television fiction has traditionally been a springboard for debutants that, after their success on TV, make the leap to the big screen.

5 A. (female) Barcelona, grupo 18-23 años: Claro si ponen a un personaje atractivo, las chicas jóvenes como nosotras, o más jóvenes porque ahora empiezan muy pronto, pues se fijan mucho y llaman la atención. ¿Por qué te crees que ponen al Mario Casas en El barco y no al Luisma?

6 L. (female) Zaragoza, grupo 24-29 años: A mí me gustan las series en las que los personajes cambian, el que parecía bueno, de repente cae en algo que lo convierte en malo, y luego puede volver a ser bueno, y otra vez malo. A mí, esos juegos me parece que dan mucha profundidad a los personajes, y me parecen mucho más reales que no esas construcciones irreales del bueno es bueno, y el malo es malo. 


\section{Interaction}

Steel and Brown define interaction as "the cognitive, affective, and behavioral engagement with media that produces cultural meanings" (Steel and Brown, 1995, p. 558), and they assimilate it with the program reception itself. The authors define three types of interaction: cognitive, affective and behavioral. A fourth type, incorporating social aspects, should be added. This includes intercourses with family members or friends while watching live shows, as well as comments about programs on the internet (forums and social networks).

Social interaction is particularly relevant in our research, to the extent that discourses about fiction were one of the biggest incentives to regularly watch a program. For this reason, this section is focused on the different modes of viewing, the discourses about programs, and the relationship between television and the internet.

\subsection{Types of viewing}

Some participants preferred to watch their favorite programs by themselves, while others favored the company of a family member. Watching TV with siblings was the most frequent option amongst those who watch fiction with their family, while TV viewing as a couple was directly proportional to age. Female participants preferred to watch fiction alone or with their families, while men opted to share the viewing with friends whenever possible. By group ages, respondents aged 18 to 23 claimed to watch most TV fiction by themselves, those aged 15 to 17 usually shared the viewing with other family members, and the group aged 24 to 29 with their partners.

Except for single-parent homes, watching a program alone was usually the result of parents and their children having different television preferences, and it usually involves a process of "negotiation between the two sides" (Hagen, 2007). Some participants, however, avoided family reception because they were ashamed to watch certain content (usually sexual) with their parents. In fact, when covering this topic during the focus group interviews, it provoked murmurs, whispered conversations and knowing smiles among the participants. Isolated viewing did not only depend on the program but also on the time of day. Thus, everyday meals (lunch or dinner) had an impact on family viewing, turning television reception into an activity closely connected with the social life of households (Barkhuus and Brown, 2009). It was found that watching television alone was no longer considered a negative experience, mainly due to the feeling of company derived from the internet (Barkhuus, 2009). 
Besides being an important source of entertainment, fiction frequently became an object of discourse among young people. Hence, fiction acts as a link with others in family, school and work environments. Closeness was a crucial factor among participants in the focus groups to determine whom to talk to regarding television: $80 \%$ of participants usually talked to friends, although this option was still compatible with conversations with siblings, partners and parents. Unlike conversations with friends, conversations with parents and siblings only take place while watching the program.

Female participants used fiction as a topic for conversation with their parents more often than men. So did the age group 15 to 17, although they also frequently commented the shows with their friends. Respondents aged 18 to 23, however, tended to talk about fiction with their siblings. A greater dispersion is observed in the group aged 24 to 29 , with the exception of conversations with their partners.

\subsection{Television and/or internet}

Most participants usually watched fiction on the TV set, although more than half also watched online programming. Family reception usually takes place in front of the main TV set at home, while isolated viewing or with siblings was usually online. Female respondents watched more fiction on the TV set than men. There were hardly any differences by age groups regarding this type of reception, except among the participants aged 18 to 23, who clearly favored the internet.

Young people from our research who watched fiction on the TV set tended to focus only on this activity. People aged 15 to 17, however, usually multitasked, doing their homework while watching TV shows and, usually, commenting with friends through their mobile phones. Occasionally, some participants combined TV viewing with housekeeping chores. A few interviewees used the internet (particularly social networks) while watching programs on the TV set.

Online viewing predisposed participants to combine it with other activities, such as social networking. This seems to suggest a more disperse reception, compared to the exclusive viewing in front of the TV set. Most of those who follow fiction on the internet opted to stream programs on the official websites or other pages that provide the content. Some respondents download the programs in order to watch them offline or on the TV set, but only when this provides better image and sound quality than the computer.

Almost half of the interviewees occasionally accessed the online resources of their favorite fiction shows, with no notable differences according to gender 
or age. The most popular social networks for gathering information or talking about fiction programs were Facebook and Tuenti. Most of those who accessed forums, program profiles or character profiles on social networks (usually official sites, but also fan pages) admitted they only do it to "snoop", and rarely left any online comments. Furthermore, only a few participants had created some type of resource (web, blog, etc.) devoted to a program, character or actor/actress. There was, however, a general tendency among the different groups to use such platforms to share pictures, videos, music and links to the website where the original material is hosted.

\section{Competence}

Symbiosis between television and the internet has played a crucial role in promoting consumption and contributing to build viewers' loyalty (Wee, 2004). Meanwhile, the current TV shows encourage viewers to "dig deeper" to understand a story (Mittell, 2009). Along with the increase on TV fiction consumption, the tendency among the youth target (most of them digital natives) to complete reception with browsing the web 2.0, has led to a remarkable increase in "semiotic competence" (Eco, 1990). Thus, the 'superculture' of the participants in our research ${ }^{7}$ includes a good knowledge of narrative techniques. This induces television consumption and increases the pleasure of reception, but also encourages critical thinking among loyal viewers.

Stimulated by the constant exchange of opinions and news in fan communities, criticism and evaluations of shows were often emotionally charged, to the extent that the respondents' interventions constantly overlapped. The most radical participants complained about American influence on domestic fiction. They accused Spanish producers and TV networks of not taking enough risks, always looking for a family target as heterogeneous and widespread as possible.

S. (male), Lleida, 18-23 years old: And something Spanish series also have, I don't know about Catalan ones, but mostly Spanish, is that they always try to make everything very family-related. They always have some adolescents and some little kids, and some old

7 The concept of "superculture" by James Lull (2001) is used to define the television culture of viewers, created by themselves in the transmedia environment that characterizes the processes of production and reception of television fiction today. 
people. And it ends up affecting the content negatively, because they are thinking about distributing ...8

On the contrary, fans particularly appreciated hybridization of genres and variety of topics. These are two extremes theoretically antagonistic, although a priori reconciled through the adaptation of different products to different modes of reception (fans and traditional viewers), as Ross (2008) points out.

On a narrative level, the main problem of fiction mentioned by participants in the focus groups is the lack of realism of certain plots. The most-criticized aspects of domestic fiction were partially conclusive or abrupt endings, as well as the excessive elongation of programs.

M. (male), Guipúzcoa, 18-23 years old: They try to extend the series for so long, when they are successful, and they attempt to lengthen and lengthen and lengthen and lengthen. A series that has three seasons is perfect, but because it is successful, then they make six, eight, ten seasons and it becomes boring. ${ }^{9}$

Respondents believed characters are built on a realistic basis, which is subsequently distorted, sometimes resulting in implausible situations. They also thought that the tendency to create extreme stereotypes and to force narrative situations to their limit to keep the viewer in suspense makes identifying with the characters difficult. Some participants found plots and characters' experiences credible. Others, however, claimed that fictional characters barely have any resemblance with young Spanish people. Nevertheless, they felt much closer to characters from domestic fiction than those from imported programs.

Treatment of certain social issues was perceived by a number of participants as something unnatural, which undermines the realism prevailing in Spanish fiction. Respondents, however, believed that Spanish fiction represents social issues adequately (immigration, homosexuality, social integration of people with disabilities, etc.) and considered that the school environment and the world of drugs are the most didactic areas tackled by fiction.

8 S. (male) Lleida, grupo de 18-23 años: I una cosa també que tenen les sèries espanyoles, catalanes no ho sé si tant, però les espanyoles sobretot que intenten fer molt familiar tot. Sempre fiquen uns adolescents, uns nens petits i un grans. I al final acaba perjudicant el contingut perquè estan pensant de repartir ...

9 M. (male) Guipúzcoa, grupo 18-23 años: Las series al final intentan alargar, cuando tienen éxito intentan alargar y alargar y alargar y alargar. Una serie que con tres temporadas está perfecta, pero como tiene éxito, pues seis, ocho, diez temporadas y al final aburre. 


\section{Application}

Application describes "the concrete ways in which adolescents use media how they make it active - in their everyday lives” (Steel and Brown, 1995, p. 559). The authors divide application in two types: appropriation and incorporation, which both include different subcategories. Appropriation is an active use of media, while incorporation is "an associative use of media that often builds on existing attitudes, feelings, and prior learning" (Steele and Brown, 1995, p. 559). Application is, therefore, the key phase of reception in the process of shaping individual identities from the social identities represented (and frequently stereotyped).

Favorite characters and shocking events comprised the most persistent memories of respondents, although most of them were not able to assign them to any specific subject matter. Consequently, despite the importance ascribed to romantic relationships and friendships, these themes were easily forgotten. Male participants' preference for comedy led to a more vivid memory of gags, compared to female participants.

Most respondents did not believe that fiction teaches anything, although they admitted it provides information on certain topics. A similar attitude was observed by Davin (2003) in his reception analysis of American medical dramas. Even so, most participants admitted that programs are an inspiration when facing certain personal and socialization problems. In addition, all focus group participants were fascinated by the characters' lifestyles, especially regarding their relational and social success. Hence, love relationships and the many possibilities for leisure in fiction represented key aspects of "wishful identification" (Hoffner and Buchanan, 2005), which respondents would like to apply to their own lives.

Since criticism of plausibility was inversely proportional to age, identification/projection with characters was more common among younger participants, especially with regard to characterization (speech and clothing) or settings (home, school, workplace, etc.). Gender, however, does not seem to influence the processes of identification/projection involved in fiction. Instead, respondents were aware of the feedback process between programs and viewers, especially regarding representation. For instance, a large number of participants considered that, while fiction reflects how young people talk, the fact remains that viewers, especially men, tend to repeat words and expressions used by certain television characters.

The role of style in the processes of feedback is similar to that of language. Thus, while television professionals are inspired by young people in the street to develop their characters, participants' fascination with characters' style often 
lead them to imitate their hairstyles and wardrobes. Female respondents aged 15 to 17 were more likely to adapt the style of characters to their own, a practice traditionally associated to adolescence (Murray, 1999).

\subsection{Transmedia processes}

Regardless of the degree of enthusiasm and loyalty to the program, respondents hardly ever bought merchandise from their favorite fictions. Free downloadable content, however, was a widespread practice among participants, who tended to assimilate illegal file sharing as a generational issue. This is consistent with the findings of Miegel and Olson (2012) in their research about internet and new forms of social intercourse.

Sneak previews of chapters/episodes in movie theaters were the most popular type of event. However, despite the many initiatives undertaken by the Spanish TV networks to promote their programs (film festival premieres; invitations to participate in the shooting; draws to dine with the stars or go with them to amusement parks and clubs, etc.), most of the respondents had never participated in any kind of cult event, ${ }^{10}$ although a few had been involved in activities such as flashmobs, castings or interviews with the cast.

\section{Conclusions}

Almost every participant admitted TV fiction has an 'addictive' quality, as verified by authors such as Millwood and Gatfield (2002). Although respondents mostly concurred that TV reception evokes the sensation of being accompanied and prevents boredom, it also seems to neutralize the feeling of experimenting "guilty pleasures" (Morley, 1986) while watching their favorite shows instead of doing other (most useful) things. The participants, however, argue the need to disconnect from everyday problems to "explain, defend and justify" reception as pure entertainment (Alasuutari, 1996, p. 102).

While choosing a program sometimes depends on the mood, friends and/ or relatives usually influence the choice, confirming the importance of fiction in youth socialization found by Aierbe, Martínez de Morentín, and Medrano (2011). Preference of female respondents for drama and isolated reception was

10 We use the concept of "cult event" (Jerslev, 1992) to designate the clash between the program and the viewer, and we understand that transmediation allows us to extend Jerslev's concept of "cult culture" to most television fictional programming. 
coherent with the greater intensity of their affective relations with programs and characters. By contrast, men's inclination towards comedy, systematically associated with having fun, leads them to prefer sharing reception with friends, as it often happens with other types of programs, such as sports. All participants in the focus groups, however, preferred to discuss fiction with their peers, which validate the findings of Thornham and Purvis (2005). On the other hand, the frequency with which respondents tend to talk to their friends reaffirmed the value of television fiction as a "catalyst" for social relationships (Madill and Goldmeier, 2003).

Our research highlights the cultural convergence between television and the internet (Jenkins, 2006). Cultural convergence allows viewers to combine "liveness reception"11 of television, associated with small rituals of everyday life, with the construction of an ideal TV programming, freed from schedules and commercials, through online viewing or downloads. In that sense, viewing programs on the computer accentuates the "discontinuity" and the "intimate" character traditionally attributed to television (Ellis, 1999).

The frequent use of the internet to recover missed broadcasts and to anticipate American fiction premieres in Spain, along with the constant feedback through resources generated by the programs, evidences its "domestication" (Barkhuus and Brown, 2009). Overall, those participants in the focus groups most active on the internet understood their activity as the construction of a sort of "boundary work rhetoric" (Winch, 1997), which allows them to be different from casual viewers. ${ }^{12}$ They also expressed their satisfaction to belong to the "web tribe" of fans (Della Torre, Boccia Artieri, Caliandro, and Giordano, 2010).

Participants tended to easily forget most of what they watched, which supports the hypothesis proposed by Grandío (2009) that people tend to consume television casually and quickly in order to obtain instant gratification. Difficulties to remember plots or even topics, however, contrasted with the persistency in the memory of the most beloved characters and the most shocking situations. This suggests that the conscious memory of programs could be sustained on a sort of catalogue of decontextualized 'snapshots'.

Participants in the focus group widely criticized the tendency to take stereotypes to the extreme. Nevertheless, they also considered that the proximity

11 Therefore, it is clear that the emphasis on simulating the 'liveness' of the programs remains one of the main assets of television, as pointed out by Jane Feuer in 1983.

12 Samuel Winch borrows the concept of "boundary work rhetoric" from the sociology of science to define "the rhetorical strategy of one group wishing to distinguish itself from another” (Winch, 1997, p. 3). 
of the topics covered in domestic fiction largely offset other shortcomings. This seems to revalidate the association of taste with the cultural knowledge of a specific group, suggested by Kuipers (2006). On the contrary, our research did not find any indications that allow associating the cultural differences with the nation-based us vs. them distinctions, as found by Kalviknes Bore (2011) in a study regarding comedy in Norway and the United Kingdom.

The greater affinity of participants in our research with characters from Spanish fiction, however, suggests the possible existence of some type of 'cultural discount' (Lozano, 2011), derived from the greater difficulty identifying with characters from foreign fiction. The greater involvement of participants with domestic fiction could also explain that characters and stories native to them appear to be more realistic than North American ones. The criticism of certain programs, however, suggests that it is not a rational realism but an "emotional realism" (Ang, 1985, 2007).

Participants used some characters as a source of 'inspiration' to confront their own emotional problems, which supports the identification with characters observed in other Spanish investigations (Grandío, 2007). However, they did not explicitly recognize and were not willing to admit that programs could modify, or have any effect on, their prior ideology and values (Slater, Ronner, and Long, 2006), even if similarities perceived between Spanish characters' problems and their own show the rising of fiction. This finding is consistent with other research showing the reduction of resistance to persuasion in the dramatic narrative (Moyer-Gusé and Nabi, 2010; Slater and Ronner, 2002), or the influence of the type of program on the viewers' attitudes (ACMA, 2011; Kort-Butler, 2011).

Consistent with denying a possible influence of fiction, the embarrassment experienced by most of the participants in relation to sexual content when reception is shared with their parents, suggests the possibility of a Third-Person Effect, ${ }^{13}$ which may be worth exploring in subsequent investigations.

Similarly to previous research about the didactic nature of Spanish fiction (Medrano, 2007) in the shaping of social identities (Lacalle, 2005, 2008) and national identities (Castelló, 2007), the present investigation revalidates the hypothesis that television narrative is a crucial source of learning for young people, as found by Gray (2005). Likewise, our research also points out the increasing role of internet in the "empowerment" of TV content by viewers (Borelli, 2008), as well as the "social desirability" generated by the promotion

13 Following W. Phillips Davidson (1983), Joan Conners defines the Third-Person Effect as "the perceptual distinction that the media will be not influential upon oneself, but rather they will be influential on others" (Conners, 2005, p. 3). 
of programs through the web (Webster and Ksiazek, 2012) largely conducted by viewers themselves. Hence the need to develop new conceptual understandings aiming to accommodate the research to evolution in media form and media delivery (Carolyn, 2009).

Acknowledgments: This article is part of a larger research project entitled 'Analysis of the construction of youth identity in television fiction and new technologies' (CSO2010-19691), funded by the Ministry of Science and Innovation (Government of Spain). This part of the investigation was developed by Charo Lacalle (director) and researchers Mariluz Sánchez and Lucía Trabajo. Contributors included Ana Cano, Deborah Castro, Beatriz Gómez, Uaika Maruri, Alba Tobella and Berta Trullàs.

\section{References}

ACMA. 2011. Digital Australians. Expectations about media content in a converging media environment. Qualitative and quantitative research report. Retrieved February 24, 2013 from http://www.acma.gov.au/webwr/_assets/main/lib410130/digital_australianscomplete.pdf.

Aierbe, A., Martínez de Morentín, J., \& Medrano, C. 2011. Preferencias televisivas, personajes de identificación e interacción familiar: un estudio transcultural con adolescentes [TV preferences, identification with characters and family interaction: a cross-cultural study of adolescents]. VI Congreso Internacional de Psicología y Educación y III Congreso Nacional de Psicología de la Educación. Retrieved January 18, 2013 from http://www.actualidaduniversitaria.com/2011/04/aprendiendo-en-las-aulascomo-ver-la-television/.

Alasuutari, P. 1996. Television as a moral issue. In P. Crawford \& S. Hafsteinsson (Eds.), The construction of the viewer: Media ethnography and the anthropology of audiences (pp. 101-117). Højbjerg: Intervention Press.

Ang, I. 1985. Watching Dallas. Soap opera and the melodramatic imagination. London: Methuen.

Ang, I. 2007. Television fictions around the world: Melodrama and irony in global perspective. Critical Studies in Television, 2(2), 18-30.

Barkhuus, L. 2009. Television on the internet: New practices, new viewers. In CHl'09 proceedings of the $27^{\text {th }}$ international conference extended abstracts (pp. 2479-2488). New York: ACM Press. Retrieved February 24, 2013 from http://cseweb.ucsd.edu/ $\sim$ barkhuus/television-altchi.pdf.

Barkhuus, L., \& Brown, B. 2009. Unpacking the television: User practices around a changing technology. ACM Transactions on Computer-Human Interaction, 16(3), 1-22.

Baym, N. 2000. Tune in, log on. Soaps, fandom, and online community. London: Sage Publications.

Bentley, G. 1987. Ethnicity and practice. Comparative Studies in Society and History, 29(1), 24-55. 
Biltereyst, D. 1991. Resisting American hegemony: A comparative analysis of the reception of domestic and US fiction. European Journal of Communication, 6(4), 469-497.

Borelli, D. 2008. Il mondo che siamo. Per una sociologia dei media e dei linguaggi digitali. Napoli: Liguori Editori.

Bourdieu, P. 1990. The logic of practice. Stanford, CA: Stanford University Press.

Brown, B., \& Barkhuus, L. 2011. Changing practices of family television watching. In R. Harper (Ed.), The connected home: The future of domestic life (pp. 93-110). London: Springer.

Carolyn, M. 2009. (Re)contextualising audience receptions of reality TV. Participations. Journal of Reception \& Reception Studies, 6(1), 137-170.

Castelló, E. 2007. Sèries de ficció i construcció nacional. Imaginant una Catalunya televisiva [TV fiction and nation building. Imagining a televised Catalonia]. Tarragona: Publicacions de la URV.

Conners, J. 2005. Understanding the third-person effect. Communication Research Trends, 24(2), 1-43.

Davidson, W. 1983. The third-person effect in communication. Public Opinion Quarterly, 47(1), 3-15.

Davin, S., 2003. Healthy viewing: the reception of medical narratives. Sociology of Health \& Illness, 25(6), 662-679.

Della Torre, A., Boccia Artieri, G., Caliandro, A., \& Giordano, A. 2010. Il caso True Blood: consumo telefilmico su media digitali. Le rappresentazioni culturali dei serial addicted: consumo, identità e resistenza [The Case of True Blood: TV viewing in digital media. Cultural representations of TV drama addicts: consumption, identity and resistance]. Centro Studi Etnografia Digitale. Retrieved February 26, 2013 from http:// www.etnografiadigitale.it.

Eco, U. 1990. I limiti dell'interpretazione [The limits of interpretation]. Milano: Bompiani.

Ellis, J. 1999. Television as working-through. In J. Grispud (Ed.), Television and common knowledge (pp. 55-70). London: Routledge.

Feuer, J. 1983. The conception of live television: Ontology as ideology. In A. Kaplan (Ed.), Regarding television: Critical approaches. An anthology (pp. 12-21). Frederick, MD: University Publications of America.

Gavin, J. 2001. Television teen-drama and HIV/AIDS: The Role of genre in audience understandings of safe sex. Continuum: Journal of Media and Cultural Studies, 15(1), 77-96.

Grandío, M. 2007. Recepción de la ficción televisiva norteamericana en España. El caso de Friends [American TV drama reception in Spain. The case of Friends]. Revista da Associação Nacional dos Programas de Pós-Graduação em Comunicação. Retrieved February 25, 2013 from http://www.compos.org.br.

Grandío, M. 2009. El entretenimiento televisivo. Un estudio de audiencia desde la noción de "gusto" [TV entertainment. An audience study trough the concept of "liking"]. Comunicación y Sociedad, XXII(2), 139-158.

Gray, J. 2005. Television teaching: Parody, The Simpsons, and media literacy education. Critical Studies in Media Communication, 22(3), 223-238.

Gumperz, J. 1992. Contextualization and understanding. In A. Duranti \& C. Goodwin (Eds.), Rethinking context: Language as an interactive phenomenon (pp. 229-252). Cambridge: Cambridge University Press. 
Hagen, I. 2007. "We can't just sit the whole day watching TV": Negotiations concerning media use among youngsters and their parents. Young. Nordic Journal of Young Research, 15(4), 369-393.

Hobson, D. 1982. “Crossroads": The drama of a soap opera. London: Methuen.

Hoffner, C., \& Buchanan, M. 2005. Young adults' wishful identification with television characters: The role of perceived similarity and character attributes. Media Psychology, 7(4), 325-351.

Hoijer, B. 1990. Studying viewers' reception of television programs: Theoretical and methodological considerations. European Journal of Communication, 5(1), 29-56.

Holliman, R. 2005. Reception analyses of science news: Evaluating focus groups as a method. Sociologia e Ricerca Sociale, 26(76-77), 254-264.

Jenkins, H. 2006. Convergence culture. New York: New York University Press cop.

Jerslev, A. 1992. Semiotics by instinct. Cult film? As a Signifying practice between audience and film. In M. Skovmand \& K. Schoreder (Eds.), Reappraising transnational media (pp. 181-198). London: Routledge.

Kalviknes Bore, I. 2011. Transnational TV comedy audiences. Television \& New Media, 12(4), 347-369.

Kitzinger, J. 1994. The methodology of focus groups: The importance of interaction between research participants. Sociology of Health \& Illness, 16(1), 103-121.

Kort-Butler, L. 2011. Watching the detectives: Crime programming, fear of crime, and attitudes about the criminal justice system. The Sociological Quarterly, 52(1), 36-55.

Kuipers, G. 2006. Television and taste hierarchy: The case of Dutch television comedy. Media, Culture \& Society, 28(3), 359-378.

Lacalle, Ch. 2005. Educar a través de la televisión. La representación del enfermo de Sida en los formatos televisivos de ficción [Educating through television. The representation of AIDS patients in TV fiction formats]. In Ch. Lacalle (Ed.), Los formatos de la televisión (pp. 31-39). DeSignis, 7-8.

Lacalle, Ch. 2008. El discurso televisivo sobre la inmigración [TV discourse on immigration]. Barcelona: Omega. Lacalle, Ch. (2013).

Lacalle, Ch. 2013. Jóvenes y ficción televisiva. Construcción de identidad y transmedialidad [Youth and TV fiction. Construction of identity and transmediality]. Barcelona: UOCPress.

Lacalle, Ch., Castro, D., \& Sánchez, M. 2014. Spain: The boom of fiction set in the past. In G. Orozco \& M. I. Vasallo De Lopes (Eds.), Yearbook Obitel 2014. Transmedia production strategies in television fiction (pp. 267-308). Porto Alegre, Editora Meridional Ltda. Retrieved September 26, 2014 from http://blogdoobitel.files.wordpress.com/2012/09/ anuacc81rio-2014-inglecc82s.pdf.

Lacalle, Ch. 2010. Joves i ficció televisiva: representacions i efectes. Anàlisi [Young people and TV fiction: representations and effects]. Quaderns de Comunicació i Cultura, 40, 29-45.

Lemish, D. 1998. Girls can wrestle too: Gender differences in the consumption of a television wrestling series. Sex Roles, 38(9-10), 833-850.

Livingstone, S. 1991. Audience reception: The role of the viewer in retelling romantic drama. London: LSE Research Online. Retrieved February 24, 2013 from http:// eprints.Ise.ac.uk/999.

Losito, G. 2009. La ricerca sociale sui media [Social research on media]. Roma: Carocci.

Lozano, J. C. 2011. Consumption of US television and films in Northeastern Mexico. International Communication Gazette, 73(8), 685-705. 
Lull, J. 2001. Culture in the communication age. London: Routledge.

Lunt, P., \& Livingstone, S. 1996. Rethinking the focus group in media and communications research. London: LSE Research Online. Retrieved February 24, 2013 from http:// eprints.Ise.ac.uk/archive/00000409.

Madill, A., \& Goldmeier, R. 2003. EastEnders: Texts of female desire and of community. International Journal of Cultural Studies, 6(4), 471-494.

Medrano, C. 2007. The teaching and learning of values through television. International Review of Education, 53(1), 5-21.

Miegel, F., \& Olsson, T. 2012. A generational thing? The internet and new forms of social intercourse. Journal of Media \& Cultural Studies, 26(3), 487-499.

Millwood, A., \& Gatfield, L. 2002. Soap box or soft soap? Audience attitudes to the British soap opera. London: Broadcasting Standards Commission. Retrieved January 30, 2013 from http://www.ofcom.org.uk/static/archive/bsc/pdfs/research/soap.pdf.

Mittell, J. 2006. Narrative complexity in contemporary American television. The Velvet Light Trap, 58, 29-40. Retrieved May 30, 2013 from http://justtv.files.wordpress.com/2010/ 12 /mittell-narrative-complexity.pdf.

Mittell, J. 2009. Lost in a great story. In R. Pearson (Ed.), Reading Lost: Perspectives on a hit television show (pp. 119-129). New York: Tauris.

Modlesky, T. 1979. The search for tomorrow in today's soap operas. Notes on a feminine narrative form. Film Quarterly, 33(1), 12-21.

Morley, D. 1980. The nationwide audience. London: BFI.

Morley, D. 1986. Family television: Cultural power and domestic leisure. London: Routledge.

Moyer-Gusé, E., \& Nabi, R. 2010. Explaining the effects of narrative in an entertainment television program: Overcoming resistance to persuasion. Human Communication Research, 36(1), 26-52.

Murray, S. 1999. Saving our so-called lives: Girls fandom, adolescent subjectivity and My so-calle life. In M. Kinder (Ed.) Kid's media culture. Durham, NC: Duke University Press, 221-235.

Ross, S. 2008. Beyond the box: Television and the internet. Malden, MA: Blackwell Publishing.

Slater, M., \& Ronner, D. 2002. Entertainment-education and elaboration likelihood: Understanding the processing of narrative persuasion. Communication Theory, 12(2), 173-191.

Slater, M., Ronner, D., \& Long, M. 2006. Dramas and support for controversial public policies: Effects and mechanisms. Journal of Communication, 56(2), 235-252.

Steel, J., \& Brown, J. 1995. Adolescent room culture: Studying media in the context or everyday life. Journal of Youth and Adolescence, 24(5), 551-575.

Stevens, P. 1996. Focus groups: Collecting aggregate-level data to understand community health phenomena. Public Health Nursing, 13(3), 170-176.

Thornham, S., \& Purvis, T. 2005. Television drama. Theories and identities. New York: Palgrave MacMillan.

Von Feilitzen, C. 2008. Children and media literacy: Critique, practice, democracy. Doxa, 6, 317-332.

Vygotsky, L. 1978. Mind in society: The development of higher psychological processes. Cambridge, MA: Harvard University Press.

Weaver, A., \& Wilson, B. 2009. The role of graphic and sanitized violence in the enjoyment of television dramas. Human Communication Research, 35(3), 442-463. 
Webster, J. G. \& Ksiazek, T. B. 2012. The Dynamics of Audience Fragmentation: Public Attention in an Age of Digital Media. Journal of Communication, 62, 39-56.

Wee, V. 2004. Selling teen culture: How the American multi-media conglomeration reshaped teen television in the 1990s. In G. Davis \& K. Dickinson (Eds.), Teen TV: Genre, consumption and identity (pp. 87-98). London: BFI Publishing.

Wertsch, J. 1991. Voices of the mind: A sociocultural approach to mediated action. Cambridge, MA: Harvard University Press.

Wilkinson, S. 1998. Focus groups in health research: Exploring the meanings of health and illness. Journal of Health Psychology, 3(3), 329-348.

Winch, S. 1997. Mapping the cultural space of journalism: How journalists distinguish news from entertainment. Westport, CT, London: Praeger.

\section{Bionote}

\section{Charo Lacalle}

Charo Lacalle is Professor of Semiotics of Communication at the Department of Journalism and Communication Science at the Autonomous University of Barcelona. 
Copyright of Communications: The European Journal of Communication Research is the property of De Gruyter and its content may not be copied or emailed to multiple sites or posted to a listserv without the copyright holder's express written permission. However, users may print, download, or email articles for individual use. 